\title{
Mastering the Unmasterable? \\ Vergangenheitsbewältigung of Germany's National Socialist past
}

\author{
ISABEL GRELAK ${ }^{1}$ \\ University of New South Wales \\ i.grelak@student.unsw.edu.au
}

\begin{abstract}
"The question about what nations should do about a difficult past is one of the great subjects of our time." 2 This essay engages with the process of Vergangenheitsbewältigung and asks the thorny question: how close is Germany to mastering a Nazi past notoriously described as "unmasterable"? ${ }^{3}$ Following discussion defining the scope of Holocaust victims and what overcoming the past entails, focus turns to the Memorial to the Murdered Jews of Europe.' Drawing insight from prominent discourse, its commemorative aims and functions are examined. Ultimately, it is concluded that whilst the memorial has brought Germany somewhat closer to coming to terms with its past by ensuring the Holocaust does not pass from public consciousness; it also consolidates a hierarchy of victims.

Without seeking to diminish or challenge the suffering of the six million J ews killed in the Holocaust, this essay highlights the exclusive nature of commemorative practice in Germany, impeding its ability to come to terms with all of its Nazi crimes.
\end{abstract}

Key words: Germany, Holocaust, memorial, Nazi, past, unmasterable.

"The question about what nations should do about a difficult past is one of the great subjects of our time."4 It is a question that touches all of humanity, yet presents no simple answers. It is amidst a backdrop of memory discourse engaging with this question that Germany's struggle to master its National Socialist past has commanded global attention. This essay engages with the process of Vergangenheitsbewältigung and asks the thorny question: how close is Germany to mastering a past notoriously described as "unmasterable"? 5

Following a discussion of what Vergangenheitsbewältigung entails and the various actors involved in the associated debates, the aims and functions of German public memory work in the new millennium will be examined. Particular focus will be placed on the controversial 'Memorial to the Murdered J ews of Europe,' unveiled in 2005 in Berlin. The fulfilment of the memorial's primary aims suggest that Germany is making undeniable progress in coming to terms with its past. Indeed, argument will be made that the end goal of mastering the past is to be encouraged; however, it will be proposed that the aims of Vergangenheitsbewältigung are narrow in their

\footnotetext{
${ }^{1}$ Isabel Grelak has recently returned from exchange in Berlin and is currently completing a combined bachelor of International Studies and Law at the University of New South Wales. She is the winner of the undergraduate section of the CESAA Essay Competition, 2010.

${ }^{2}$ T. G. Ash, 'Trials, Purges and History Lessons', in History of the Present: Essays, Sketches and Despatches from Europe in the 1990s, London, 1999. p.294.

${ }^{3}$ C. Maier, The unmasterable past: History, holocaust, and German national, Harvard University

Press, Cambridge, Mass, 1988.

${ }^{4}$ Ash, op. cit.

${ }^{5}$ Maier, op.cit.
} 
scope of commemoration. This creates a hierarchy of victims, functioning as a substantive obstacle to mastery of Germany's National Socialist past, in its entirety.

\section{Vergangenheitsbewältigung: An Overview}

In discussing coming to terms with the National Socialist past, it is necessary to delineate, for the present purpose, exactly which past it encompasses. This essay focuses on the Holocaust aspect of National Socialism; however, the definition of the Holocaust, or more specifically the scope of its victims, remains hotly contested. 6

The definition adopted here incorporates all minority and "racially motivated German crimes and all their victims" and, although exact figures are impossible to produce, there is suggestion that the tally of victims may have approached seventeen million. ${ }^{7}$ The victims are taken to include, among others, the European J ewish community, the Sinti and Roma, the handicapped, homosexuals, Polish and Soviet civilians, prisoners of war and political and religious dissenters. The reasons for this "expansive conceptualisation" 8 will be evidenced in a later discussion of the hierarchisation of victims.

A further concept requiring clarification is Vergangenheitsbewältigung. Combining the German words for 'past' and 'overcoming', it is a term that conceptualises 'coming to terms with the past,' ordinarily within a framework of politics, policy and culture. 9 Once again, a more expansive definition will be adopted in this essay; one that superimposes conventional politics with Erinnerungspolitik ${ }^{10}$ (memory politics) to allow for a better analysis of working through the past through commemorative practice. 11

In arguing that Germany's past is indeed masterable, it is also useful to elucidate what the process does not involve. It does not and should not entail an "Aufrechnung (reckoning up or settling of accounts), drawing a line below the ledger of moral accountability or laying the past to rest."12 It does not involve drawing a Schlussstrich ${ }^{13}$ but rather a continually evolving dialogue and an active practice of commemoration. Mastering the past is not about achieving justice or "seeking moral closure". 14

\footnotetext{
${ }^{6}$ For example, see multiple definitions in: D. Niewyk. 'The Colombia Guide to the Holocaust,' Colombia, Colombia University Press, 2003, pp.51-52.

${ }^{7}$ Ibid.

8 Ibid.

${ }^{9}$ A. Beattie. Playing Politics with History: The Bundestag Inquiries into East Germany, Berghahn Books, New York, 2008, p.9.

${ }^{10}$ P. Reichel. Politik mit der Erinnerung: Gedaechtnisorteim Streit um die nationalsozialistische Vergangenheit, (revised edition), Frankfurt am Main, 1999. Cited in: Andrew H. Beattie (2008)

'Playing Politics with History:The Bundestag Inquiries into East Germany', Berghahn, p.20.

${ }^{11}$ Beattie, op. cit., p.9.

${ }^{12}$ R. Moeller, The Politics of the Past in the 1950s: Rhetorics of Victimisation in East and West Germany', in Germans as Victims: Remembering the Past in Contemporary Germany, B. Niven (ed.), Houndmills, Palgrave Macmillan, 2006, p.27.

${ }^{13}$ H. Köhler: quoted in R. Wittlinger, 'Collective Memory and National Identity in the Berlin Republic: The Emergence of a New Consensus?', Debatte: J ournal of Contemporary Central and Eastern Europe, Vol.14, No. 3, 2006, p. 209.

${ }_{14}$ M. Friedman, cited in: Neill, W. J. V., 'Berlin Babylon: The Spatiality of Memory and Identity in Recent Planning for the German Capital,' Planning Theory and Practice, Vol.6, No.3, 2005, p.351.
} 
In this essay it is taken to mean moving on from a paradigm dichotomising victim and perpetrator, as the passage of time begets a generation of Germans not culpable for the crimes of their forebears. 'Vergangenheitsbewältigung', 'mastering the past' and 'coming to terms with the past' will be referred to interchangeably under this unifying definition.

The real difficulty posed by the concept, however, lies deeper than semantics. It is, in part, due to the absence of normative criteria, the fulfilment of which satisfies the requirements of a mastered past. The real test and ultimate judge is public perception, which is unlikely to achieve homogeneity. But before it can even approach consensus, commemorative practice needs to honour all victims if it indeed seeks to come to terms with the Holocaust, in its entirety.

For this reason, groups representing victims are amongst the primary actors involved in Vergangenheitsbewältigung discourse. The J ewish voice, with notable advocates such as Lea Rosh and the Central Council of Jews in Germany ${ }^{15}$ has a strong presence. Offering, at times, dissenting perspectives is the General Council of Sinti and Roma. They are joined by a long list of victim lobby groups, politicians, members of the public, designers and prominent figures. Historians also lend valuable insight to the debate, with renowned works having been published by Charles Maier, J ames E. Young and Bill Niven, amongst countless others. One of the most prominent aspects of their discourse turns on the multitudinous aims and functions of Vergangenheitsbewältigung.

\section{Aim vs. Function}

Consideration of what Vergangenheitsbewältigung seeks to do and what it actually achieves is a weighty factor in conjecturing how close Germany is to mastering its past. This is, however, by no means a simple task. Vergangenheitsbewältigung casts an expansive net through multiple facets of public, and not to mention private, life. Recent projects of relevance include; "public discussions, political debates in the Bundestag, preservation of former concentration camps, memorials, commemorative days... museums, documentaries, compensation for victims"16 and reform to the school curriculum. In light of the sheer scope of these projects, continuing discussion here in broad empirical detail presents too extensive a venture. For this reason, aims and functions will be analysed with respect to the controversial 'Memorial to the Murdered J ews of Europe,' revealed in Berlin, 2005. An additional reason for focussing on the prominent memorial is that memory and identity interact substantially with physical space; "the German word for being alive, 'Dasein' literally meaning being there'. The common view is that cultural or collective memory is produced through and reflected in object, images and representations."17

${ }^{15}$ G. Knischewski, 'Remembering in the Berlin Republic: The debate about the central Holocaust memorial in Berlin,' Debatte: J ournal of Contemporary Central and Eastern Europe, Vol.13, No.1, 2005, p.26.

${ }^{16}$ E. Langenbacher, The Mastered Past? The Impact of Collective Memories on Contemporary German Political Culture and Public Opinion' Working Paper, August 30, 2010, Georgetown University, Department of Government. Available at SSRN: http://ssrn.com/abstract=1668917, Accessed 1 Sepetmber 2010, p.22.

${ }^{17}$ L. Heidenreich, 'Collective Memory, Identity and Place Making in Reunified Berlin', Workshop on Urban Conflicts, Identities and Architecture, Available at Imgard Coninx

Stiftung:http:// www.irmgard-coninx- 
Designed by Peter Eisenman and spanning 19000 square metres at the metropolitan heart of Berlin, it is a powerful presence featuring thousands of concrete stellae. Generating heated debate since the memorial's inception by Lea Rosh in 1989, the memorial has continued to attract controversy through its dedication, design and international reception.

Aim and functionality intersect at different levels of the generated debates, demonstrating a complex interdependence. According to James E. Young, "if the reason for these memorials is 'never to forget,' then we ask precisely what is not forgotten... for what is remembered here depends on how it is remembered; and how events are remembered depends in turn on the shape memorial icons now lend them." 18 Memorial discourse draws attention to a confusing interplay of the what, the how and by whom.

Ethically, there is undeniable merit to the quest for justice following a wrong. Yet, there is arguably little place for true justice in post-millennial Vergangenheitsbewältigung. Germany is approaching a time where victims and perpetrators are no longer amongst the living. Timothy Garton Ash suggests that those who never faced the Third Reich have no right to condemn those who did and, likewise, those who were themselves not victims have no right to forgive.19 Furthermore, the argument may be advanced that justice can never be achieved for such horrific crimes, by sheer virtue of their gravity. So, setting the quest for justice aside, it must be asked what other aims motivate commemorative work such as the 'Memorial to the Murdered J ews of Europe.'

Critics such as Michael Friedman ${ }^{20}$ and Michael Naumann ${ }^{21}$ speak out against an unspoken aim of "moral closure,"22 allowing perpetrators to jettison responsibility and receive atonement. There is, however, no substantive evidence to suggest this to be a bona fide aim and certainly not on an official level. However, there are fears that this is a functional consequence of the project. A related claim is that Germany abdicates responsibility by not mentioning who it was that murdered the Jews. ${ }^{2} 3$ Aside from the perhaps superficial argument that the nationality of perpetrators is made implicit by its location in Berlin, the call for Germany to identify those culpable, as demonstrated by the Nuremberg Trials, is a task fraught with difficulty, producing what some claim to be limited justice. It also raises other questions such as whether the statuses of victim and perpetrator are mutually exclusive; an issue debated following the proposed Centre against Expulsions.

stiftung.de/fileadmin/ user_upload/pdf/ urbanplanet/identities/ws2/ 082\%20Heidenreich.pdf>, accessed 16 September, 2010, p.2.

${ }^{18} \mathrm{~J}$. E. Young, 'After the Holocaust: National Attitudes to J ews' - The Texture of Memory: Holocaust

Memorials and Meanings.' Holocaust and Genocide Studies, Vol.4, No.1, 1989, p.64.

19 T. Garton Ash, op. cit., p.301.

${ }^{20}$ Cited in: Neill, W. J . V. (2005) 'Berlin Babylon: The Spatiality of Memory and Identity in Recent

Planning for the German Capital', Planning Theory and Practice Vol.6, No.3, p.351.

${ }^{21}$ Cited in: Ibid, p.347.

22 M. Friedman, cited in: Ibid, p.351.

${ }^{23}$ S. Mangos, Thesis: 'The Construction of the National Holocaust Memorial in Berlin', 2010,

<simonemangos.com/Thesis_Holocaust_memorial_06_02-2010_senza_abstract.pdf>, accessed 10

September 2010, p. 282. 
A similar criticism focuses instead on the function of the memorial. Apprehension was voiced by Allan Cochrane at the prospect of the memorial functioning as a "place of forgetting rather than remembering." 24 Cochrane put forward the idea that "there is nothing as invisible as a monument." 25 suggesting that memorials make the past invisible and easier to forget, thus creating redemption through forgetting. Yet the axiomatic counter-argument is that there is indeed something more invisible and more conducive to forgetting than a memorial; namely the lack of one. Still, the German media embraced the concern, questioning the memorial's potential to degenerate into a Kranzabwurfstelle (a place where wreaths are 'dumped') and tourist attraction. ${ }^{26}$ The latter is debatably unavoidable but if tourism is a corollary of broader awareness, perhaps it should be welcomed, so long as it generates more discourse and consolidates public memory.

A more positive aim of the memorial favoured by such commentators as James E. Young and Brian Ladd is to "engage people in an active process of remembering"27 the Holocaust, in which "an inescapable partnership grows between a people and its monuments." 28 In his design, Eisenman aimed to trigger dialogue; "It stands there silent. The one who has to talk is you." 29 This is an instance where function undeniably follows the aim; constant debate and discussion still persist, consolidating public memory. By generating debate and discussion, this memorial project, amongst countless others, brings Germany closer to coming to terms with its past. Regardless of whether dialogue is critical or favourable, the key point is that the event doesn't pass from public consciousness. A notable publication, "Das Denkmalstreit - das Denkmal," supports this by implying that the memorial debate is (of) itself the memorial. ${ }^{30}$ The essential fact is that Germany has instituted commemorative practices that intersect with other endeavours listed above as part of the overarching Vergangenheitsbewältigung process. The primary achievement of the 'Memorial to the Murdered J ews of Europe' is that it is there, that it is accessible and thought-provoking and that there is information available for those who seek it. According to James E. Young, "this is finally all we can ask of Germany's national attempt to commemorate the Nazi's murder of European J ewry" 31 - which prompts the question; what of the 'others'?

James E. Young's statement, prima facie, suggests that Germany is indeed very near to coming to terms with the Holocaust. However, the lesser representation of the 'other' victims presents something of an obstacle. Are the aims for Holocaust commemoration too exclusively focussed on 'primary' victims?

\footnotetext{
24 B. Ladd, 'Center and Periphery in the New Berlin: Architecture, Public Art and the Search for Identity,' J ournal of Performance and Art, Vol. 22, No. 2, 2000.

${ }^{25}$ Huyssen quoted in: A. Cochrane. 'Making up Meanings in a Capital City: Power, Memory and Monuments in Berlin,' European Urban and Regional Studies Vol.13, No.5, 2006, p.12.

${ }^{26}$ Frankfurter Allgemeine Zeitung cited in: Caroline Gray, The politics of cultural remembrance: The holocaust monument in Berlin, 1999, p.160.

${ }^{27}$ J. E. Young, see J an Fischer, The Ghosts of Berlin; Confronting German History in the Urban Landscape,' Harvard Design Magazine No.7, 1999, p.349.

${ }^{28} \mathrm{~J}$. E. Young. 'After the Holocaust: National Attitudes to J ews', op. cit., p.74.

${ }^{29}$ S. Quigley, 'Holocaust Memorial: Architect Peter Eisenman,' <http:// www.war-

memorial.net/Holocaust-Memorial--Architect-Peter-Eisenman,-Berlin-2005-2.66.. , accessed 10

September, 2010.

${ }^{30}$ U. Heimrod, G. Schlusche und H. Seferens, "Der Denkmalstreit - das Denkmal? Die Debatte um

das “Denkmal für die ermordeten J uden Europas”, Philo Verlag, Berlin, 1999.

${ }^{31}$ J. E. Young cited in: The Ghosts of Berlin', op. cit., p.350.
} 


\section{How close is Germany to mastering its Nazi past?}

It is this question of the 'other' victims of Nazi crimes, it will be argued, that functions as one of the primary barriers to Germany's mastery of its past. But before this statement can be justified, it is worth examining whether the past can be mastered at all and whether it should be encouraged.

Holocaust discourse is heavy with opinion firmly rooted against such a position. Ernst Nolte summarised this sentiment clearly with his article in the Frankfurter Allgemeine Zeitung, "Die Vergangenheit, die nicht vergehen will"32(the past that will not pass). Similarly, Charles Maier wrote a book about Germany's “Unmasterable Past", 33 to which the title of this essay makes reference. This academic culture may be due, in part, to a lack of agreement on what coming to terms with the past entails. The definition delineated earlier, involving moving on from a paradigm dichotomising victim and perpetrator whilst continuing commemorative practice, finds support amongst academic commentators such as Eric Langenbacher.

Langenbacher tentatively claims that Germany's Nazi legacy "may be overcome,"34 intimating that "perhaps it is time to ask whether Germany's past finally has been worked through - not in a manipulative or evasive sense - but rather in light of good intentions and because of the power of time." 35 His use of the subjunctive mood and general reluctance to make a definitive statement on this highly controversial topic comes as little surprise. Although seemingly confident that mastering the past is possible, he too appears to hold reservations about the process being complete.

Langenbacher's hesitation notwithstanding, his confidence in Germany's theoretical capacity to come to terms with its past is shared. The Western legal tradition holds that criminal responsibility will only be attributed to those with mens rea (the guilty mind). In the present day, the third and fourth generations since the Holocaust are reaching adulthood. The vast majority of Germans today have no mens rea for Nazi crimes and yet "continue to take their self-representation very seriously. Expressions of national ambition, self-assertion or ego inspire suspicion." 36 Although it is nowhere written that the current generation of Germans are responsible for the crimes of their forebears, the damaging conceptualisation of the European J ewry as victims and Germans as perpetrators remains. Without compromising commemoration of the Holocaust, there ought to come a time when Germans can "represent (their) own interests (internationally) in a more uninhibited manner."37 There is support for the view that a time when Germany is "no longer paralysed by the memory of crimes perpetrated in its name"38 is very close. J ames E. Young asserts that Germany's involvement in NATO's 1999 intervention in Serbia is

\footnotetext{
${ }^{32}$ E. Nolte, Vergangenheit, die nicht vergehen will. Eine Rede, die geschrieben, aber nicht gehalten werden konnte, in: Frankfurter Allgemeine Zeitung, 6. J une 1986.

${ }^{33}$ C. S. Maier, op. cit.

${ }^{34}$ E. Langenbacher, Still the Unmasterable Past?, op. cit., p.24.

35 Ibid, p.36.

${ }^{36} \mathrm{~J}$. Fischer, op. cit., p.5.

${ }^{37}$ G. Schröder, "Eine offenen Republik", Die Zeit, 1999 quoted in: Ruth Wittlinger. (2006) 'Collective Memory and National Identity, p.208.

38 J. E. Young, Germany's Holocaust memorial problem - and mine, op. cit., p.80.
} 
demonstrative that "endless debate and memorialisation are no longer mere substitutes for actions against contemporary genocide but reasons for action."

"Germany has gone furthest in commemoration"39 having "transformed utterly the values, institutions and social structures that made the Third Reich and Holocaust possible." 40 There is even recent suggestion that Germany's Vergangenheitsbewältigung "could be instructive and even exemplary for Europe."41 However, despite such positive reception, there exist flaws in Holocaust commemorative practice.

Positively answering the question of whether mastery of the Nazi past is possible, or even desirable, is not to say that Germany has succeeded. Analysis must instead be directed towards a final inquiry; what is preventing completion of the process? The question has attracted much speculation with suggested impediments including the flat impossibility of morally coming to terms with such heinous crimes, the reemergence of Germans-as-victims discourse, the overshadowing of commemoration by "political bickering" 42 and the hierarchisation of victims. Opinion on the subject is diverse and, at times, highly emotional. Unfortunately, substantial discussion cannot be dedicated to all potential impediments to mastering the past. For this reason, attention in this essay will focus on the hierarchisation of Holocaust victims, tending towards the ultimate conclusion that Germany cannot master its Nazi legacy, in its entirety, without adequately commemorating all of its victims without preferential treatment.

Perhaps the most resounding backlash surrounding the Memorial to the Murdered J ews of Europe' comes from activist groups and scholars representing the millions of other victims that suffered as part of the Holocaust. The argument was advanced that by dedicating the largest and most significant memorial in Berlin solely to J ewish victims killed, a hierarchisation of victims was created. Not only does it exclude J ewish victims who survived the torment but countless people of other race and identity. As, arguably, Germany's flagship memorial to all the world, the exclusion created the sentiment that 'other' victims are less worthy of commemoration. Controversially deemed the "second selection process conducted by the Germans," 43 some were quick to remind "it was the Nazi state that started dividing its victims into different groups. Why does this have to be continued sixty years after the downfall of the regime?" 44

Much discourse focussed on the uniqueness of the J ewish experience. Lea Rosh head of the Foundation for the Memorial to the Murdered J ews of Europe maintained that "the J ews are the most important victim group and therefore have priority." 45 "Other victim groups," she added, "can legitimately expect memorials of their own." 46 It

39 T. G. Ash, op. cit., p.309.

40 E. Langenbacher, Still the Unmasterable Past, op. cit., p.37.

${ }^{41}$ A. Beattie, Learning from the Germans,' J ournal of Multidisciplinary International Studies, Vol 4, No 2, 2007, p.3.

$42 \mathrm{~J}$. E. Young cited in: The Ghosts of Berlin, op. cit., p.21.

43 G. Knischewski, 'Remembering in the Berlin Republic', p.39.

${ }^{44}$ Die Welt, quoted in: <http://news.bbc.co.uk/2/hi/europe/4533463.stm>, accessed 10 September, 2010.

45 K. E. Till, op. cit., p.126.

${ }^{46}$ L. Rosh, quoted in Neill, Memory and Identity in Recent Planning, op. cit., p.348. 
must be asked whether such dialogue is constructive for the task of coming to terms with the past. Other victim groups can expect commemoration but this is not to say that they will receive it; it is not the place of victims to construct memorials for themselves. Following much public discussion, subsequent memorials to homosexual victims and the Roma and Sinti were erected nearby but their lesser size suggested lesser significance, not to mention that further victim groups were left unmentioned. Bill Niven takes the argument further by asking, "does the fact that six million J ews were killed, but 'only' 500, 000 Sinti and Roma, make the individual death of a J ew more significant than that of a Sinto?"47 The answer must surely be in the negative, justifying in turn a more expansive definition of the Holocaust to avoid a damaging hierarchisation.

The argument presented here does not seek to diminish or challenge the suffering of the six million J ews killed in the Holocaust. Instead, it aims to reveal discrimination ingrained in the scope of memorial practice with vision to make it more inclusive and comprehensive. Commemoration is, after all, not a zero sum game where the remembrance of additional victims compromises that of other victim groups. If Germany seeks to eventually come to terms with all of its Nazi past and move on from a dichotomisation of victims and perpetrators, it needs to commemorate all of the victims without preferential treatment. The cost of an individual human life should be deemed no greater or lesser in significance than any other. "With the Memorial for the Murdered Jews of Europe used as Germany's world wide advertisement of its recognition of its crimes... and as the official 'national memory of the Holocaust,' a grave injustice has been cemented in place for all of the victims." 48 Perhaps the dedication of the memorial site should be broadened to include all victims of Nazi crimes like the Neue Wache memorial in Berlin. Whether this could be achieved with sensitivity and without inciting uproar, however, is a question perhaps no one is in a position to answer.

\section{Conclusion}

The conclusion drawn here regarding Germany's post-millennial process of Vergangenheitsbewältigung is bitter-sweet. Germany has demonstrated great commitment to consolidating commemorative practice and generating awareness about the Holocaust. Indeed, in this respect Germany's efforts may be exemplary for the rest of Europe. The combination of this success with the passage of time may suggest that the legacy of the Nazi past is close to being overcome. This would allow Germany to move beyond the dichotomisation of victim and perpetrator and, whilst maintaining active commemoration, assert itself without censure or suspicion.

The reluctance of scholarship and commentary to declare that this process has been completed, with public opinion being the ultimate judge, suggests there to be an obstacle impeding mastery of the past. Although it is impossible to discern a single and definitive reason from the complex interweave of Holocaust discourse, it is asserted in this essay that a significant unresolved factor is the hierarchisation of victims. The commemoration of some victim groups in preference to others consolidates segregation and the dichotomisation of victim and perpetrator. Were

${ }^{47}$ B. Niven, Facing the Nazi Past: United Germany and the Legacy of the Third Reich, London, Routledge, 2001, p.214.

48 S. Mangos, op. cit., p.286. 
this issue to be addressed, Germany would progress far closer to its ultimate goal of coming to terms with its Nazi past, in all of its entirety. 